\title{
Induced Systemic Resistance by Rhizosphere and Phyllosphere Microorganism against Root Rot caused by Sclerotium rolfsii in Tropical Sugarbeet (TSB) Ecosystems
}

\author{
Paramasivan Mookkan* and N. Muthukrishnan
}

\author{
${ }^{\text {(}}$ Plant Pathology), Dryland Agricultural Research Station, \\ TNAU, Chettinad, TamilNadu, India \\ ${ }^{2}$ (Agricultural Entomology), TamilNadu Agricultural University, \\ Coimbatore, TamilNadu, India
}

*Corresponding author

\author{
A B S T R A C T
}

\begin{tabular}{|l|}
\hline Ke y w o r d s \\
Rhizosphere, \\
Phylloplane, \\
pseudomonas \\
fluorescens and \\
Induced systemic \\
Resistance
\end{tabular}

Phylloplane and rhizosphere microorganism were isolated from tropical sugarbeet. Phyllolplane fungi viz., Cladosporum sp., Penicillium sp., Aspergillus niger, Aspergillus flavus, and Curvularia and Bacteria of $B$. subtilis and $P$. fluorescens were isolated seven phylloplane microorganisms tested, Pseudomonas fluorescens significantly recorded maximum per cent mycelial growth reduction (41.90), sclerotial Number (70.65 per cent) and Sclerotial germination (58.67\%) reduction over control. Among rhizosphere forty four Pseudomonas fluorescens and six isolates of Bacillus subtilis and Trichoderma sp 31 isolates tested for their antagonistic activity against Scerotium rolfsii by dual culture, one isolate namely T.viride (TVB 1) P. fluorescens (SBHRPF 2), B. subtilis (SBHRBS1) showed highest per cent mycelial growth inhibition allowed minimum of sclerotial production. Pot culture experiments The application of biocontrol agents triggered the activity of three defense related enzymes viz., peroxidase (PO), polyphenol oxidase (PPO) and phenylalanine ammonia lyase (PAL) were induced and the accumulation of phenol was also noticed in Tropical sugarbeet upon challenge inoculation soil application S.rolfsii the causal agent for root rot in tropical sugarbeet. The activities of defense enzymes reached a peak at four days after inoculation (DAI) with the pathogen. Native PAGE analysis revealed the expression of an additional isoforms of PO and PPO were observed in biocontrol agents treated soil application due to induced systemic resistance (ISR) induction.

\section{Introduction}

The world harvested 301 million metric tonnes of sugar beets (Beta vulgaris L. ssp. vulgaris var. altissima) in 2017. The world's largest producer was Russia, with a 51.9 million-metric-tonne harvest. The average yield of sugar beet crops worldwide was 58.2 tonnes per hectare. The root of the sugar beet is $20 \%$ sugar, $5 \%$ pulp, and $75 \%$ water. The sugar of the sugar beet is of primary value and the pulp left after sugar extraction is used as animal feed. The byproducts of this crop include molasses and pulp and this adds a further $10 \%$ value to the cash crop. Now India introduced tropical sugar beet varieties are gaining momentum in tropical and subtropical countries. 
New crop introduced in climatic condition the severe Root rot caused by Sclerotium rolfsiiis a major problem in all the tropical sugar beet growing areas. Intensive cultivation of tropical sugar beet has resulted in the increased occurrence of root rot. seedling blight Utter Pradesh in India (Mukhopadhyay, 1971). Leach (1934) recovered the pathogen from the soils of sugar beet fields in California. Paramasivan et al., (2014) reported that root rot caused by $30 \%$ yield loses and it management with Trichoderma viride. As an ecologically viable alternative, biological control has been a desirable strategy for controlling plant diseases (You et al., 2015) and there are an increasing number of biocontrol agents (BCAs), such as Bacillus spp., Pseudomonas spp., Trichoderma spp. etc., being commercialized for various crops (Cha et al., 2016) Plant has endogenous defense mechanisms that can be induced in response to attack by insects and pathogens (Bostock et al., 2001). Defense reaction occurs due to the accumulation of PR-proteins, phytoalexins, chalcone synthase, PAL, PO, PPO and phenolics. The objective of the present study is to unravel the induction of various defense related genes encoding proteins implicated in strengthening of plant cell walls by biocontrol agents treatments in response to infection by S.rolfsii in tropical sugarbeet ecosystems.

\section{Materials and Methods}

Isolation of phylloplane and rhizosphere microorganism in tropical sugarbeet ecosystem

Phylloplane microorganisms were isolated from three different tropical sugarbeet varieties, viz., Indus, cavury and subraja. The active fresh leaves were collected and cut into small bits by mean of a sterile scalpel. The leaf bits were suspended in three $\mathrm{ml}$ of sterile distilled water and thoroughly shaken for five minutes and allowed to stand for five minutes. From this one $\mathrm{ml}$ of suspension was pipetted out into each sterilized Petri dish using a sterilized pipette. Fifteen $\mathrm{ml}$ of PDA medium was poured each of these plates, gently swirled and allowed to solidify. For bacteria, nutrient agar medium was used. Three replications were maintained for each treatments. Sterile water added plates served as control. The plates were incubated at room temperature. Forty eight hours after incubation, the bacterial colonies were sub cultured and subsequently purified by streak plate method (Rangaswamy and Soumini Rajagopalan, 1973). The fungal colonies were sub cultured after 3-5 days and purified by single hyphal tip method. (Rangaswami, 1972). The fungal and bacterial cultures isolated were maintained on PDA, King's B and nutrient agar slants respectively for further studies.

\section{Isolation of native antagonists}

Soil antagonistic microbes viz., Trichoderma sp., Pseudomonas sp. and Bacillus sp. were isolated from the rhizosphere soil using Trichoderma selective medium (TSM) (Elad and Chet, 1983), King's B medium (King et al., 1954) and Nutrient agar medium (NA) (Difco manual, 1953) respectively. Morphological identification was made through the light microscope and pure cultures were maintained on respective agar slants at $4^{\circ} \mathrm{C}$.

Pseudomonas sp. = SBHRPF1 to SBHRPF 21, SBHPPF22 to SBHRPF30, SBDPPF31 to SBDPPF36 and SBDRPF 37 to 44 and Bacillus sp. = SBHRBS 1, SBHPBS 2, SBDRBS3, SBHPBS 4, SBHRBS 5 and BHRBS 6.

Efficacy of phylloplane organism against Sclerotium rolfsii. 
A nine mm actively growing culture disc of the fungus was placed onto sterilized Petri dish containing previous plated and solidified PDA medium approximately $1.5 \mathrm{~cm}$ away from the edge of the plate. In the same way, a nine $\mathrm{mm}$ culture disc of the purified phylloplane test fungus was placed on the medium at the opposite side of the fungus causing root rot. For bacteria, the fungus alone was placed and the actively growing 48 h old bacterial culture was separately streaked onto the medium at the opposite side of the plate. Similarly three replications were maintained for each treatment. PDA medium inoculated with the pathogen alone served as control.

\section{Effect of biocontrol agents on the induction of defense related enzyme in tropical sugar beet plants}

Two months old tropical sugarbeet plants were treated with the biocontrol agents $T$ .viride (TVB1), T. harzianum (THB1), $P$. fluorescens isolate (SBHRPF 2), $P$. chlororaphis isolate PA23 and B. subtilis isolate (SBHRBS 1) by soil application and challenged with $S$. rolfsii $\left(\mathrm{SBSR}_{3}\right)$ mass multiplied in sand maize medium.

Tropical sugarbeet plant along with tubers was carefully removed from the pots after 0 , $2,4,6,8$, and 10 days after challenge inoculation with $S$. rolfsii and washed several times with sterile distilled water before enzyme extraction. The enzymes were extracted separately from both leaf and tubers at ice-cold condition $\left(5^{\circ} \mathrm{C}\right)$. The samples were homogenized with phosphate buffer (1 $\mathrm{g}$ of leaf or tubers with $1 \mathrm{ml}$ of sodium phosphate buffer $(0.1 \mathrm{M}) \mathrm{pH} 7.0)$. The homogenates were centrifuged at $10,000 \mathrm{rpm}$ for $15 \mathrm{~min}$. The supernatant was used as enzyme source for peroxidase (PO), polyphenol oxidase (PPO), phenylalanine ammonia-lyase (PAL), and phenol assay.

\section{Peroxidase activity (PO)}

One gram of fresh plant tissue was ground in $1 \mathrm{ml}$ of $0.1 \mathrm{M}$ phosphate buffer with $\mathrm{pH} 7.0$ in a pre-cooled pestle and mortar. The homogenate was centrifuged at 15,000 rpm at $4^{\circ} \mathrm{C}$ for $15 \mathrm{~min}$. The supernatant was used as enzyme source. The reaction mixture consists of $1.5 \mathrm{ml}$ of $0.05 \mathrm{M}$ pyrogallol, $0.1 \mathrm{ml}$ of enzyme extract and $0.5 \mathrm{ml}$ of one per cent $\mathrm{H}_{2} \mathrm{O}_{2}$. The change in absorbance of the reaction mixture was recorded at $420 \mathrm{~nm}$ at $30 \mathrm{sec}$ interval for $3 \mathrm{~min}$. at room temperature $\left(28 \pm 2^{\circ} \mathrm{C}\right)$. The boiled enzyme preparation served as blank. The enzyme activity was expressed as change in absorbance of the reaction mixture per min. per $\mathrm{g}$ of leaf or tuber (Hammerschmidt et al., 1982).

\section{Polyphenol oxidase (PPO)}

One gram of fresh plant sample was ground in $1 \mathrm{ml}$ of $0.1 \mathrm{M}$ sodium phosphate buffer $(\mathrm{pH}$ 6.5). The homogenate was centrifuged at $15,000 \mathrm{~g}$ for $15 \mathrm{~min}$. at $4^{\circ} \mathrm{C}$ and the supernatant was used as the enzyme source. The reaction mixture consisted of $1.5 \mathrm{ml}$ of $0.1 \mathrm{M}$ sodium phosphate buffer $\mathrm{pH} 6.5$ and 0.1 $\mathrm{ml}$ of the enzyme extract. The reaction was initiated by the addition of $0.2 \mathrm{ml}$ of catechol $(0.01 \mathrm{M})$. The activity was expressed as change in absorbance at $495 \mathrm{~nm}$ at $30 \mathrm{sec}$ interval for $3 \mathrm{~min}$. The enzyme activity was expressed as change in absorbance per min. per $g$ of leaf or tuber (Mayer et al., 1965).

\section{Phenylalanine ammonia lyase (PAL)}

Five hundred $\mathrm{mg}$ of plant material was homogenized in $5 \mathrm{ml}$ of cold $25 \mathrm{mM}$ borate $\mathrm{HCl}$ buffer $(\mathrm{pH} \quad 8.8)$ containing $5 \mathrm{mM}$ mercaptoethanol $0.4 \mathrm{ml}$ per 1. The homogenate was centrifuged at $15,000 \mathrm{~g}$ for $15 \mathrm{~min}$. and the supernatant was used as enzyme source. The assay mixture consists of $0.2 \mathrm{ml}$ of enzyme extract, $1.3 \mathrm{ml}$ water and 
$0.5 \mathrm{ml}$ borate buffer. The reaction was initiated by the addition of $1 \mathrm{ml}$ of $12 \mathrm{mM} \mathrm{L}$ Phenylalanine. The reaction mixture was incubated for $1 \mathrm{~h}$ at $32^{\circ} \mathrm{C}$. The reaction was stopped by the addition of $0.5 \mathrm{ml}$ of $2 \mathrm{~N} \mathrm{HCl}$. A blank was run in which phenylalanine was added after adding $2 \mathrm{~N} \mathrm{HCl}$. The absorbance was measured at $290 \mathrm{~nm}$. The enzyme activity was expressed as $\mu \mathrm{mol}$ of cinnamic acid/ $\mathrm{min} /$ $\mathrm{g}$ of leaf or tuber (Dickerson et al., 1984).

\section{Phenols}

One gram of the sample was ground in a pestle and mortar in $10 \mathrm{ml}$ of 80 per cent methanol. The homogenate was centrifuged at $10,000 \mathrm{~g}$ for $20 \mathrm{~min}$. The supernatant was evaporated to dryness and the residue was dissolved in $5 \mathrm{ml}$ of distilled water. From this $0.2 \mathrm{ml}$ was taken and the volume was made up to $3 \mathrm{ml}$ with distilled water. To that $0.25 \mathrm{ml}$ of Folin-Ciocalteau reagent $(1 \mathrm{~N})$ was added. After $3 \mathrm{~min} .1 \mathrm{ml}$ of 20 per cent sodium carbonate was added and mixed thoroughly. Then the tubes were placed in boiling water for $1 \mathrm{~min}$. and cooled. The absorbance was measured at $725 \mathrm{~nm}$ against a reagent blank. The phenol activity was expressed in $\mu \mathrm{g}$ of catechol per $\mathrm{g}$ of plant tissue (Zieslin and Ben Zaken, 1993).

\section{Native gel electrophoresis}

Plant samples were collected on the $4^{\text {th }}$ day after challenge inoculation with pathogen at which the activity of PO and PPO will be higher.

The protein extract was prepared by homogenizing $1 \mathrm{~g}$ of plant sample in $1 \mathrm{ml}$ of $0.1 \mathrm{M}$ sodium phosphate buffer $(\mathrm{pH}$ 7.0) and centrifuged at $16,000 \mathrm{~g}$ for $20 \mathrm{~min}$. at $4^{\circ} \mathrm{C}$. The protein content of the sample was determined by Broadford method (Bradford, 1976). Sample (50 $\mu \mathrm{g}$ protein) was loaded onto $8 \%$ polyacrylamide gels for the analysis of PO and PPO isoforms. (Sigma, USA). After electrophoresis, PO isoforms were visualized by soaking the gels in 0.05 per cent benzidine in dark for 30min. (Sigma, USA) (Laemmli, 1970) in acetate buffer (20mM, pH 4.2). After incubation $\mathrm{H}_{2} \mathrm{O}_{2}$ was added drop wise (Nadlony and Sequira, 1980). For assessing PPO isoforms profile, the gels were equilibrated in dark for $30 \mathrm{~min}$. in 0.1 per cent p-phenylenediamine in $0.1 \mathrm{M}$ phosphate buffer ( $\mathrm{pH}$ 7.0) followed by the addition of $10 \mathrm{mM}$ catechol in the phosphate buffer (Jayaraman et al., 1987).

\section{Results and Discussion}

Efficacy of phylloplane and rhizosphere biocides against $S$. rolfsii in vitro

Among the six phylloplane microorganisms tested, Pseudomonas fluorescens significantly recorded maximum per cent mycelial growth reduction (41.90) over control followed by Aspergillus flavus and Bacillus subtilis which recorded 39.18 and 39.00 per cent inhibition respectively and these were on par with each other. The minimum inhibition was exerted by Curvularia sp and Penicillium sp which recorded 21.48 and 21.32 per cent inhibition respectively (Table 1). Among seven rhizosphere microorganisms Trichoderma viride recorded maximum per cent mycelial growth reduction 66.81 per cent reduction over control, followed by $P$. fluorescens and A. niger which recorded 50.96 per cent inhibition and these were on par with each other. The minimum inhibition was noted in Rhizopus spp which showed 20.72 per cent inhibition (Table 1a).

\section{Number of sclerotia}

Among the six phylloplane microorganisms $P$. fluorescens showed the maximum reduction of sclerotial production which was recorded 70.65 per cent followed by $B$. 
subtilis and A. flavus which recorded 58.05 and 56.30 per cent reduction respectively. (Table1). Among rhizosphere microorganisms T.viride significantly recorded 69.16 per cent sclerotial reduction over control (Table 1a) followed by rhizosphere $P$. fluorescens recorded 64.85 per cent reduction.

\section{Sclerotial germination}

Among the six phylloplane microorganisms $P$ fluorescens recorded maximum sclerotial germination inhibition of 58.67 per cent followed by $B$. subtilis and A. flavus which recorded 52.67 and 51.67 per cent inhibition respectively and these were on par with each other (Table 1) Among rhizosphere microorganism T.viride was recorded minimum sclerotial germination 37.50 per cent when compared to control which recorded 100.00 per cent germinations (Table 1a)

Effect of fungal antagonists against $S$. rolfsii in vitro (Dual culture technique)

Among best four isolates of T.viride Viz., TVB1, TVB2, TVB3 and TVB31 and Two isolates of $T$. harzianum viz., THB1 and THB2 were tested under in vitro condition. Among the ten fungal antagonists tested $\mathrm{T}$. viride (TVB 1) significantly exerted highest per cent mycelial growth inhibition of (73.03) over control. Followed by $T$. harzianum (THB1) and $T$. viride (TVB 2) recorded of 71.19 per cent mycelial growth inhibition over the control and on par with each other. (Table 2).

\section{Sclerotial number and sclerotial germination}

The sclerotial production of S. rolfsii was also assessed in dual culture technique with ten fungal antagonists of Trichoderma spp. Among the isolates screened TVB1 allowed minimum of sclerotial production (28.04/plate) and less germination (31.22 per cent) followed by THB 1 which recorded 29.36 sclerotia / plate as against the control (204.93/palte) among the fungal antagonist Chaetomium globosum allowed maximum sclerotia production with less inhibition 129.69 followed by T.reesei 95.04 when compare to other Trichoderma isolates. (Table 2)

Screening of rhizosphere and phylloplane bacterial antagonist against the mycelial growth of $S$. rolfsii

Among the forty four isolates of Pseudomonas fluorescens and six isolates of Bacillus subtilis tested for their antagonistic activity against $S$. rolfsii by dual culture, one isolate namely $P$. fluorescens (SBHRPF 2) were found to be effective (Table 3). $P$. fluorescens (SBHRPF 2) showed highest per cent mycelial growth inhibition 66.74, over control. Among the isolates of B. subtilis, screened for antifungal activity against Sclerotium rolfsii, SBHRBS1 recorded 51.01 per cent reduction of mycelial growth over control (Table 3). The mycelial growth of S.rolfsii recorded in dual plates of SBHRBS 1 and SBHRBS 6 were $4.36 \mathrm{~cm}$ and $4.46 \mathrm{~cm}$ respectively as compared to control (8.90 $\mathrm{cm})$.

Induction of systemic resistance by antagonists

Biochemical changes in tropical sugar beet plants treated with antagonists

The biochemical changes were assessed in tropical sugar beet plants treated with the antagonists on challenge inoculation with Sclerotium rolfsii. The activities of phenol a peroxidase, polyphenol oxidase were monitored upto10 days after challenge inoculation. In general the enzyme activities 
were higher in treatments treated with the antagonists compared to healthy and inoculated control.

\section{Effect of antagonists in peroxidase enzyme activity}

Induction of peroxidase enzyme activity also in both the fungal and bacterial antagonists induced the activity of peroxidase in tropical sugar beet leaf and tuber. The enzyme activity was more in antagonists application and subsequently inoculated with $S$. rolfsii In all the treatments the enzyme activity showed an increasing trend up to four days after treatment and there after a decline in the enzyme activity was observed. The plants treated with $T$. viride (TVB1) and subsequently inoculated with S.rolfsii recorded the maximum induction of peroxidase activity (0.253 changes in absorbance/min/g/of tissue) in the leaves followed by $T$. viride (TVB1) alone treated plants (0.226) as against control (healthy) (0.173). A similar trend was observed in the activity of peroxidase in the tuber also (Fig. $1)$.

\section{Effect of antagonists in Polyphenol oxidase enzyme activity}

The sugar beet plants expressed higher activity of PPO when challenged with pathogen irrespective of pretreatment with biocontrol agents. Although an increase in PPO activity began from $2^{\text {nd }}$ day after challenge inoculation, accumulation reached maximum on $4^{\text {th }}$ day after inoculation with the T. viride (TVB1) and subsequently inoculated with S.rolfsii which recorded in sugar beet 0.283 changes in absorbance $/ \mathrm{min} / \mathrm{g}$ of tissues in leaves and 0.355 changes in absorbance $/ \mathrm{min} / \mathrm{g}$ of tissues in tuber) followed by P.fluorescens and subsequently inoculated with S.rolfsii (0.268 and 0.308) as against control (0.197 and 0.222) (Fig. 2).

\section{Effect of biocontrol agents on Phenylalanine ammonia lyase (PAL) activity}

The enzyme activity in the pretreated and challenged plants increased from the $2^{\text {nd }}$ day after inoculation and maintained at higherlevel upto $6^{\text {th }}$ day after challenge inoculation. Whereas in healthy and inoculated (S.rolfsii) control plants the activity was decreased many folds lower than in pretreated plants with biocontrol agents with challenge inoculated plants Among the biocontrol agents, pretreatment of sugarbeet plants (leaves ) with the $T$. viride (TVB1) and subsequently inoculated with S.rolfsii recorded the maximum PAL activity of 37.49 nmol transcinnamic acid on $2^{\text {nd }}$ day after challenge inoculation and increased up to $6^{\text {th }}$ day (53.29 nmol transcinnamic acid) followed by a slow decline after $6^{\text {th }}$ day (Figure 3). But the activity of PAL in inoculated control was only 27.63 on $2^{\text {nd }}$ day after challenge inoculation and 34.54 on $6^{\text {th }}$ day in sugarbeet leaves similarly in sugarbeet plants root the pretreatment Trichoderma viride (TVB1) and subsequently inoculated with $S$. rolfsii recorded the maximum PAL activity of 40.09 on $2^{\text {nd }}$ day after challenge inoculation and increased upto $6^{\text {th }}$ day (57.55) followed by a slow decline after $6^{\text {th }}$ day But the activity of PAL in inoculated control was only 30.45 on $2^{\text {nd }}$ day after challenge inoculation and 38.08 on $6^{\text {th }}$ day in roots (Fig3).

\section{Effect of antagonists on phenolics}

In all the treatment there was an increasing trend in total phenol content of the leaf and tuber from zero to four days after treatment. S. rolfsii alone inoculated plants recorded the phenolic content of $0.638 \mathrm{mg} / \mathrm{g}$ in leaf and $0.672 \mathrm{mg} / \mathrm{g}$ in tuber. Sugar beet plants inoculated with $T$. viride (TVB1) and subsequently inoculated with S.rolfsii 
recorded $0.850 \mathrm{mg} / \mathrm{g}$ in leaf and $0.915 \mathrm{mg} / \mathrm{g}$ in tuber of total phenols as against control $(0.440 \mathrm{mg} / \mathrm{g}$ and $0.432 \mathrm{mg} / \mathrm{g}$ respectively) four DAT (Fig 4) these were followed by the plants treated with P.fluorescens isolate SBHRPF $2(0.840$ and $0.881 \mathrm{mg} / \mathrm{g})$ and $T$. harzianum isolate THB1 and inoculated with S.rolfsii (0.780 and $0.713 \mathrm{mg} / \mathrm{g}$ respectively).

\section{Native gel electrophoresis}

\section{Isoform pattern of peroxidase}

Native gel electrophoretic separation of enzyme extract from biocontrol agents treated plants challenged with S.rolfsii showed different peroxidase $(\mathrm{PO})$ isoform patterns in both sugarbeet leaves and tuber. In T.viride isolateTVB1 and P.fluorescens isolate SBHRPF 2 after challenge inoculation with S.rolfsii showed 3 isoforms PO1- PO2, but in the healthy control no isoform were expressed. The intensity of expression of $\mathrm{PO} 2$ was more pronounced TVB1 and SBHRPF2 alone and also challenge inoculation of S.rolfsii with an additional expression of $\mathrm{PO} 3$ (SBHRPF2) than healthy control. (Plate 1).

Native gel electrophoretic separation of enzyme extract from biocontrol treated sugarbeet tuber showed different peroxidase (PO) patterns in sugarbeet tubers. The plants treat with $P$. fluorescens (SBHRPF2) along with challenge inoculation $S$. rolfsii showed 5 isoforms PO1-PO5, but in control (without pathogen inoculation) plant revealed only two isoform. PO1 and PO2 induced in bacterized tubers as well as bacterized tubers followed by challenge inoculation with S.rolfsii

The expression of PO3-PO5 were absent in $T$. viride (TVB1) inoculated control and Healthy control, but isoform PO5 was induced when the pathogen inoculated with in SBHRPF2 along pathogen challenge inoculation (Plate 1a).

\section{Isoform pattern of polyphenol oxidase}

Isoform pattern of the PPO in the sugarbeet plants challenged with or without S.rolfsii were studied. The PPO isoform pattern of biocontrol agents treated sugarbeet plants (leaves) after challenge inoculation with pathogen revealed the presence of 3 isoforms in sugarbeet leaves. PPO1 was present in all the plants irrespective of the treatments, but PPO3 was detected only in plants treated with P.fluorescens isolate SBHRPF2 and T. viride isolate TVB1 challenged with S.rolfsii.

But PPO1 and PPO2 remain as dark band. But in the healthy control plants the isoforms PPO1 and PPO2 were observed as a faint band. The unique enzyme band of PPO2 was not observed in gels of extracts prepared from leaf tissues of biocontrol agents (TVB1) alone treated plants without challenge inoculation (Plate 2). But the same band (PPO2) appeared with higher intensity in biocontrol agents treated plants, challenged with pathogen than in uninoculated healthy plants.

Isoform pattern of the PPO was studied in sugarbeet root also, The PPO isozyme pattern of biocontrol agents treated tissues taken from sugarbeet tuber after challenge inoculation with pathogen revealed the presence of a unique isozyme PPO3 and PPO4 detected only in the fungal and bacterial bioagents treated plant and remains as dark band without change over time. But in the control plants the isozyme PPO3 and PPO4 are absent. The unique enzyme band (PPO 4 and PPO 5) was not visible in gels of extracts prepared from tuber tissues of control plant. But the intensity of the isoforms (PPO1 and $\mathrm{PPO} 2$ ) was comparatively faint when compared to fungal and bacterial bioagents alone treated sugarbeet tubers. The PPO3, $\mathrm{PPO} 4$ and PPO5 isoforms were induced in P.fluorescens isolate SBHRPF 2 and T.viride isolate TVB1treated tubers (Plate 2a). 
Use of biocontrol agents are considered as an alternative to chemicals for the management of crop diseases. $P$. fluorescens from phylloplane and T.viride from Rhizosphere exerted the maximum reduction of pathogen. Pseudomonas fluorescens and P. putida were isolated from the spermosphere of sugarbeet in California (Osburn et al., 1989). Fulkui et al., (1994) reported that Pseudomonas from sugarbeet spermosphere system effectively controlled P. ultimum. Qin et al., (2019) the efects of two diferent BCAs on the phyllosphere microbial community and further revealed the potential relationships between phyllosphere bacterial community and plant health.

The isolates $T$. viride (TVB1), T.harzianum (THB1) $P$. fluorescens (SBHRPF1) and $P$. chlororaphis (PA 23) caused drastic reduction in sclerotial production by the pathogen. This has a practical bearing in the control of this pathogen which survives in soil in the form of sclerotia. Therefore reduction in sclerotial production by the antagonist will reduce the inoculum potential and subsequently disease incidence. Rangeshwaran and Prasad (2000) reported eleven rhizobacteria antagonistic to S.rolfsii including P. fluorescens, P. putida, Streptomyces spp. and Bacillus spp. which completely inhibited S.rolfsii under dual culture by the production of antibiotics or lytic enzymes

\section{Induced systemic resistance by antagonists}

Plants have endogenous defense mechanisms that can be induced in response to attack by insects and pathogens ( Heil, 2001). It is well known that the defense genes are inducible genes and appropriate stimuli or signals are needed to activate them. Inducing the plant's own defense mechanisms by prior application of a biological inducer is thought to be a novel plant protection strategy. Induced resistance by inducing agents in several crops is associated with enhancement of lignification and with increased activities of defense gene products that are involved in phenyl propanoid pathway and PR protein synthesis ( Hammerschmidt and Kuc, 1995). The activities of the defense enzymes superoxide dismutase (SOD), peroxidase (POX) and glutathione reductase (GR) increased strongly in Dasht in response to $M$. albescens infection (Dariush Ebadi Almas and Atefeh Rahmani Kamrod., 2019)

The phenolic compounds may contribute to enhance the mechanical strength of host cell wall and may also inhibit the fungal growth as phenolics are fungitoxic in nature. In the present study, increased levels of phenol accumulation were observed in T.viride (TVB1), T. harzianum (THB1) P. fluorescens (SBHRPF2) P. chlororaphis (PA23) and $B$. subtilis (SBHRPBS1) pretreated plants challenge with pathogen inoculation. In all the treatments, accumulation of phenol was more up to four days after treatment and afterwards a sudden decline was recorded. (Fig 4) Seed treatment with $P$. fluorescens 63-28 induced the accumulation of phenolics in tomato root tissues (M' Piga et al., 1997). The increased phenolic substances exhibited considerable morphological changes including cytoplasmic disorganization and loss of protoplasmic content of the pathogen. Accumulation of phenolics by prior application of $P$. fluorescens in pea has been reported groundnut against $C$. personata (Meena et al., 2000),

\section{Induction of peroxidase and poly phenol oxidase}

The antagonists along with pathogen inoculation induced more peroxidase and polyphenol oxidase activity in tropical sugarbeet plants leaf and tuber, biotic and abiotic inducers play an important role in activating the defense genes in plants ( Van 
Loon, 1997). In the present investigation, it was observed that the tropical sugarbeet plants applied with T.viride isolate (TVB1), $T$. harzianum (THB1) P.fluorescens isolate (SBHRPF2) P. chlororaphis isolate PA23 and B. subtilis isolate SBHRPBS1 significantly induced the defense compounds (peroxidase and polyphenol oxidase) compared to unsprayed control (Fig 1and 2)

Peroxidase represents another component of an early response in plants to pathogen attack and plays a key role in the biosynthesis of lignin which limits the extent of pathogen spread. Increased peroxidase (PO) has been observed in a number of resistant interaction involving plant pathogenic fungi, bacteria and virus (Nandakumar et al., 2001). Increased activity of cell wall bound peroxidase has been elicited in different plants such as cucumber (Chen et al., 2000), In the present study, peroxidase activity was significantly increased from $2^{\text {nd }}$ day after challenge inoculation. The peroxidase activity was maximum on $4^{\text {th }}$ day after challenge inoculation in tropical sugarbeet tuber and leaves pretreated with the T.viride isolate (TVB1) and P.fluorescens isolate SBHRPF2.

In the present study, the total of five isozymes (PO1-PO5) was detected in T.viride (TVB1) and $P$. fluorescens (SBHRPF2), treated plants with $S$. rolfsii challenge inoculation. The expressions of PO2, and PO3 were higher in leaves pretreated with the biocontrol agents (T.viride isolate TVB and $1 P$. fluorescens isolate SBHRPF2) pretreated plants challenged with pathogen when compared with plants treated with biocontrol agents alone, pathogen alone and healthy. But in case of tropical sugarbeet tubers, PO4 and PO5 were induced in fungal and bacterized tubers as well as followed by challenge inoculation with $S$. rolfsii $P O$ was found to accumulate with concomitant increase in the lignin in plants treated with biocontrol agents following pathogen infection. Peroxidase reduces $\mathrm{H}_{2} \mathrm{O}_{2}$ to water at the expense of electron from coniferyl alcohol and the process initiates the lignifications chain reaction in plants (Smith et al., 1991). It has been established that lignin depositions from barriers limit fungal penetration. The early and increased expression of the peroxidase enzymes would have involved in the biochemical reaction necessary for lignification which protected the plants from $S$. rolfsii infection. In the present investigation, PPO activity was increased from $2^{\text {nd }}$ day after challenge inoculation, but maximum activity was recorded on $4^{\text {th }}$ day after challenge inoculation with pathogen in all the biocontrol agents treated tropical sugarbeet leaves and tubers, Meena et al., (2000) reported that the $P$. fluorescens induced the activities of PPO in response to infection by $C$. personata in groundnut.

The present experiment demonstrated that the application of T.viride isolate TVB1 and P.fluorescens isolate SBHRPF2 induced the polyphenol oxidase (PPO) activity in leaves. Five isoforms were observed in tropical sugarbeet plants pre treated with biocontrol agents followed by challenge inoculation with pathogen. PPO3 was detected only in plants treated with SBHRPF2 and TVB1 challenged with $S$. rolfsii. The isoform PPO3 was not observed in plants treated with biocontrol agents alone without challenge inoculation.

But in tropical sugarbeet tubers, PPO4 and PPO5 isoforms are induced by TVB1 and SBHRPF 2. The isoform PPO4 and PPO5 was not observed in plants treated with biocontrol agents alone without challenge inoculation.The induction of PO and PPO might have resulted in cell wall thickening and would have suppressed the penetration of $S$. rolfsii into tropical sugarbeet plants. 
Table.1 Antagonistic effect of phylloplane biocides against $S$. rolfsii in vitro

\begin{tabular}{|l|l|c|c|c|c|c|c|}
\hline $\begin{array}{l}\text { S } \\
\text { No }\end{array}$ & Treatments & \multicolumn{2}{|c|}{ Mycelial growth* } & \multicolumn{2}{|c|}{$\begin{array}{c}\text { Number of } \\
\text { sclerotia* }\end{array}$} & \multicolumn{2}{|c|}{$\begin{array}{c}\text { Sclerotial } \\
\text { germination*(\%) }\end{array}$} \\
\cline { 3 - 9 } & & $\begin{array}{c}\text { Mycelial } \\
\text { growth } \\
\text { (cm) }\end{array}$ & $\begin{array}{c}\text { Growth } \\
\text { inhibition } \\
\text { (\%) }\end{array}$ & $\begin{array}{c}\text { No. of } \\
\text { sclerotia/ } \\
\text { plate }\end{array}$ & $\begin{array}{c}\text { Per cent } \\
\text { reduction }\end{array}$ & $\begin{array}{c}\text { Sclerotial } \\
\text { germination } \\
\text { (\%) }\end{array}$ & $\begin{array}{c}\text { Per cent } \\
\text { reduction }\end{array}$ \\
\hline $\mathbf{1}$ & Aspergillus flavus & 5.37 & 39.18 & 91.33 & 56.30 & 48.33 & $\mathbf{5 1 . 6 7}$ \\
\hline $\mathbf{2}$ & Cladosporum & 6.33 & 28.31 & 181.33 & 13.23 & 67.33 & $\mathbf{3 2 . 6 7}$ \\
\hline $\mathbf{3}$ & Curvularia & 6.93 & 21.48 & 192.33 & 7.97 & 65.33 & $\mathbf{3 4 . 6 7}$ \\
\hline $\mathbf{4}$ & Penicillium spp & 6.77 & 23.32 & 189.67 & 9.25 & 61.66 & $\mathbf{3 8 . 3 4}$ \\
\hline $\mathbf{5}$ & $\begin{array}{l}\text { Pseudomonas } \\
\text { fluorescens }\end{array}$ & 5.13 & 41.90 & 61.33 & 70.65 & 41.33 & $\mathbf{5 8 . 6 7}$ \\
\hline $\mathbf{6}$ & Bacillus subtilis & 5.33 & 39.00 & 87.67 & 58.05 & 47.33 & $\mathbf{5 2 . 6 7}$ \\
\hline $\mathbf{7}$ & Control & 8.83 & - & 209.00 & - & 100 & \\
\hline & CD $(\mathbf{P = 0 . 0 5 )}$ & $\mathbf{0 . 6 8}$ & & $\mathbf{2 . 2 3}$ & & $\mathbf{2 . 6 6}$ & \\
\hline
\end{tabular}

* Mean of three replications

Table.1a Antagonitic effect of rhizosphere biocides against S. rolfsii in vitro

\begin{tabular}{|c|c|c|c|c|c|c|c|}
\hline \multirow[t]{2}{*}{$\begin{array}{l}\text { S. } \\
\text { No }\end{array}$} & \multirow[t]{2}{*}{ Treatments } & \multicolumn{2}{|c|}{ Mycelial growth* } & \multicolumn{2}{|c|}{$\begin{array}{l}\text { Number of } \\
\text { sclerotia* }\end{array}$} & \multicolumn{2}{|c|}{$\begin{array}{c}\text { Sclerotial } \\
\text { germination* }(\%)\end{array}$} \\
\hline & & $\begin{array}{l}\text { Mycelial } \\
\text { growth } \\
\text { (cm) }\end{array}$ & $\begin{array}{c}\text { Growth } \\
\text { inhibition } \\
(\%)\end{array}$ & $\begin{array}{l}\text { No. of } \\
\text { sclerotia/ } \\
\text { plate }\end{array}$ & $\begin{array}{l}\text { Per cent } \\
\text { reduction }\end{array}$ & $\begin{array}{c}\text { Sclerotial } \\
\text { germination } \\
(\%)\end{array}$ & $\begin{array}{l}\text { Per cent } \\
\text { reduction }\end{array}$ \\
\hline 1 & $\begin{array}{l}\text { Aspergillus } \\
\text { niger }\end{array}$ & 4.33 & 50.96 & 66.33 & 54.87 & 59.20 & 40.80 \\
\hline 2 & $\begin{array}{l}\text { Aspergillus } \\
\text { flavus }\end{array}$ & 5.47 & 38.05 & 78.00 & 46.93 & 67.10 & 32.90 \\
\hline 3 & Penicillium spp & 6.67 & 24.46 & 99.67 & 32.19 & 69.07 & 30.93 \\
\hline 4 & Rhizopus spp & 7.00 & 20.72 & 112.33 & 23.58 & 67.10 & 32.90 \\
\hline 5 & $\begin{array}{l}\text { Trichoderma } \\
\text { viride }\end{array}$ & 2.93 & 66.81 & 45.33 & 69.16 & 37.50 & 62.50 \\
\hline 6 & $\begin{array}{l}\text { Pseudomonas } \\
\text { fluorescens }\end{array}$ & 4.33 & 50.96 & 51.67 & 64.85 & 39.47 & 60.53 \\
\hline 7 & Bacillus subtilis & 4.67 & 47.12 & 64.00 & 56.46 & 45.39 & 54.61 \\
\hline 8 & Control & 8.83 & & 147.00 & - & 100.00 & - \\
\hline & $\mathrm{CD}(\mathrm{P}=0.05)$ & 0.93 & & 3.16 & & 1.40 & \\
\hline
\end{tabular}

$*$ Mean of three replications 
Table.2 Effect of fungal antagonists against $S$. rolfsii in vitro (Dual culture technique)

\begin{tabular}{|c|c|c|c|c|c|c|c|}
\hline \multirow[t]{2}{*}{$\begin{array}{c}\text { S. } \\
\text { No }\end{array}$} & \multirow[t]{2}{*}{ Treatments } & \multicolumn{2}{|c|}{ Mycelial growth (cm) } & \multicolumn{2}{|c|}{ Number of sclerotia } & \multicolumn{2}{|c|}{$\begin{array}{c}\text { Sclerotial } \\
\text { germination }(\%)\end{array}$} \\
\hline & & $\begin{array}{l}\text { *Mycelial } \\
\text { growth of } \\
\text { S. rolfsii } \\
\quad(\mathrm{cm})\end{array}$ & $\begin{array}{l}\text { Per cent } \\
\text { reduction } \\
\text { over } \\
\text { control }\end{array}$ & $\begin{array}{c}\text { No. of } \\
\text { sclerotia/ } \\
\text { plate }\end{array}$ & $\begin{array}{c}\text { Per cent } \\
\text { reduction } \\
\text { over } \\
\text { control }\end{array}$ & $\begin{array}{c}\text { Sclerotial } \\
\text { germination } \\
(\%)\end{array}$ & $\begin{array}{l}\text { Per cent } \\
\text { reduction } \\
\text { over } \\
\text { control }\end{array}$ \\
\hline 1 & T. viride (TVB1) & 2.40 & 73.03 & 28.04 & 86.31 & 31.22 & 68.78 \\
\hline 2 & T. viride (TVB2) & 2.50 & 71.19 & 31.34 & 84.70 & 34.88 & 65.12 \\
\hline 3 & T. viride (TVB3) & 2.63 & 70.44 & 36.63 & 82.12 & 38.87 & 61.13 \\
\hline 4 & T. viride(TVB31) & 2.86 & 67.86 & 34.65 & 83.09 & 40.86 & 59.14 \\
\hline 5 & T. harzianum (THB1) & 2.50 & 71.19 & 29.36 & 85.67 & 31.55 & 68.45 \\
\hline 6 & T. harzianum (THB2) & 2.96 & 66.74 & 37.748 & 81.58 & 43.18 & 56.82 \\
\hline 7 & Control & 8.86 & - & 204.93 & - & 100 & - \\
\hline & $\mathrm{CD}(\mathrm{P}=\mathbf{0 . 0 5})$ & 0.32 & - & 0.95 & - & 1.66 & - \\
\hline
\end{tabular}

* Mean of three replications

Table.3 Effect of bacterial antagonists' against $S$. rolfsii in vitro

\begin{tabular}{|c|c|c|c|c|c|c|c|}
\hline \multirow[t]{2}{*}{$\begin{array}{l}\text { S. } \\
\text { No }\end{array}$} & \multirow[t]{2}{*}{ Treatments } & \multicolumn{2}{|c|}{ Mycelial growth (cm) } & \multicolumn{2}{|c|}{ Number of sclerotia } & \multicolumn{2}{|c|}{$\begin{array}{c}\text { Sclerotial germination } \\
(\%)\end{array}$} \\
\hline & & $\begin{array}{l}\text { *Mycelial } \\
\text { growth of } \\
\text { S. rolfsii } \\
\quad(\mathrm{cm})\end{array}$ & $\begin{array}{l}\text { Per cent } \\
\text { reduction } \\
\text { over } \\
\text { control }\end{array}$ & $\begin{array}{c}\text { No. of } \\
\text { sclerotia/ } \\
\text { plate }\end{array}$ & $\begin{array}{l}\text { Per cent } \\
\text { reduction } \\
\text { over } \\
\text { control }\end{array}$ & $\begin{array}{c}\text { Sclerotial } \\
\text { germinati } \\
\text { on }(\%)\end{array}$ & $\begin{array}{l}\text { Per cent } \\
\text { reduction } \\
\text { over } \\
\text { control }\end{array}$ \\
\hline 1 & $\begin{array}{l}\text { P. fluorescens } \\
\text { (SBHRPF2) }\end{array}$ & 2.96 & 66.36 & 22.69 & 84.66 & 34.65 & 65.35 \\
\hline 2 & $\begin{array}{l}\text { P. fluorescens } \\
\text { (SBHRPF4) }\end{array}$ & 3.06 & 65.23 & 34.53 & 76.67 & 43.56 & 56.44 \\
\hline 3 & $\begin{array}{l}\text { P. fluorescens } \\
\text { (SBHRPF8) }\end{array}$ & 3.50 & 60.22 & 39.46 & 73.33 & 41.58 & 58.42 \\
\hline 4 & $\begin{array}{l}\text { P. fluorescens } \\
\text { (SBHRPF14) }\end{array}$ & 3.50 & 60.22 & 45.38 & 69.33 & 59.4 & 40.60 \\
\hline 5 & $\begin{array}{l}\text { P. fluorescens } \\
\text { (SBHRPF18) }\end{array}$ & 4.50 & 48.86 & 34.53 & 76.33 & 57.42 & 42.58 \\
\hline 6 & $\begin{array}{l}\text { P. fluorescens } \\
\text { (SBHRPF38) }\end{array}$ & 3.10 & 64.77 & 38.48 & 74.00 & 42.57 & 57.43 \\
\hline 7 & P. chlororaphis (PA 23) & 3.50 & 60.22 & 42.42 & 71.33 & 51.48 & 48.52 \\
\hline 8 & B. subtilis (SBHRBS1) & 4.36 & 50.45 & 54.27 & 63.33 & 40.59 & 59.41 \\
\hline 9 & B. subtilis (SBHRBS2) & 4.48 & 49.09 & 52.29 & 64.67 & 69.3 & 30.70 \\
\hline 10 & Control & 8.80 & - & 148.01 & - & 100 & - \\
\hline & $\mathrm{CD}(\mathrm{P}=\mathbf{0 . 0 5})$ & 0.07 & & 0.92 & & 1.29 & \\
\hline
\end{tabular}




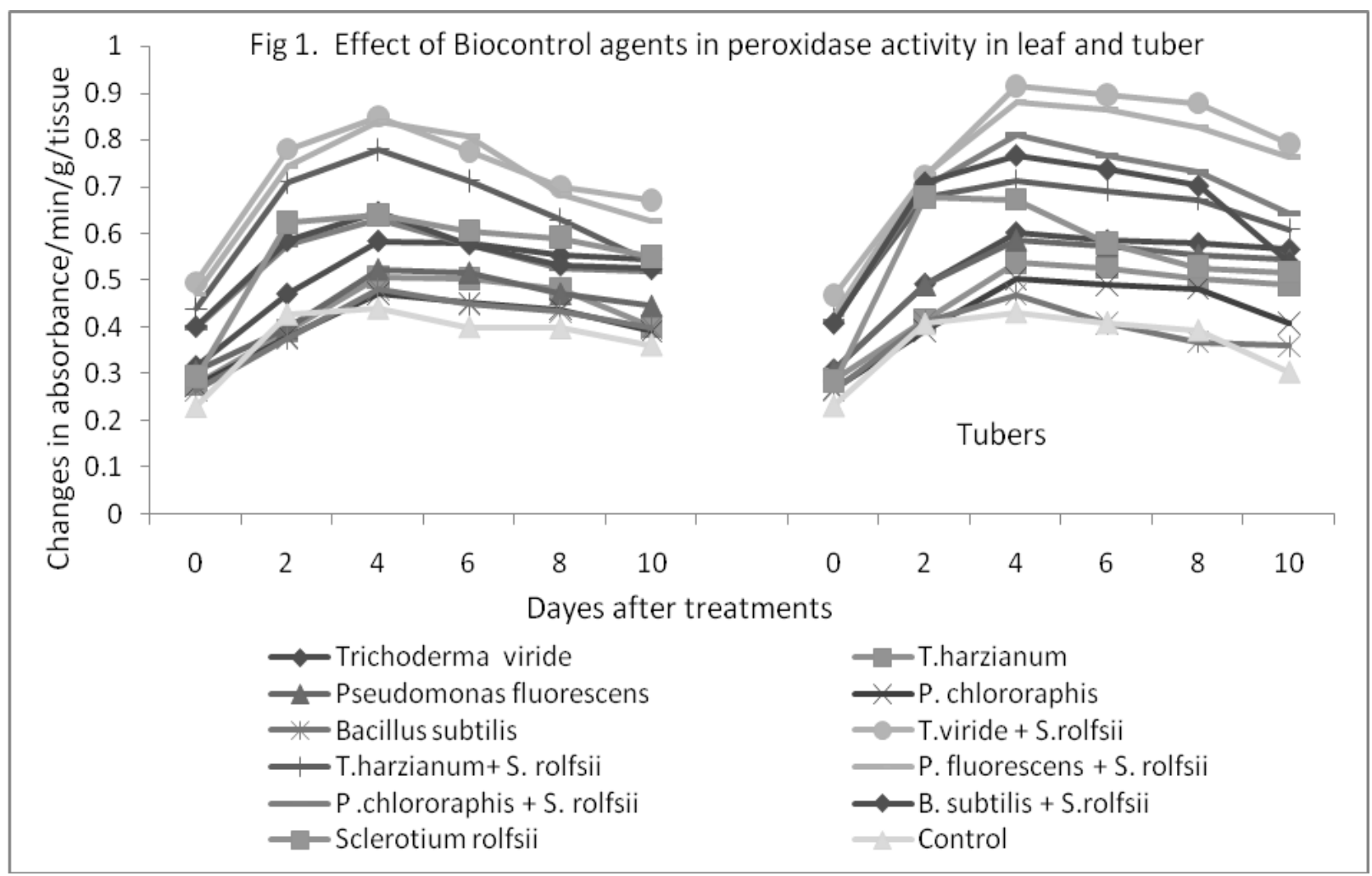

Fig.1 Effect of Biocontrol agents in peroxidase activity in leaf and tuber

Fig 2. Effect of Biocontrol agents in Polyphenol oxidase activity in leaf and tuber

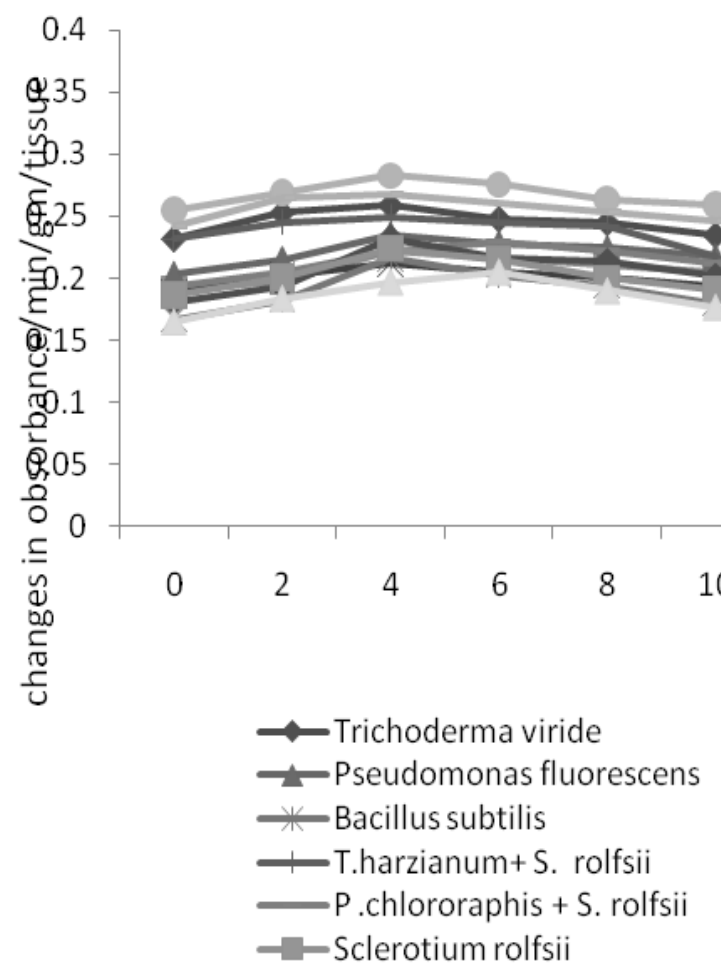

Fig.2 Effect of Biocontrol agents in Polyphenol oxidase activity in leaf and tuber 


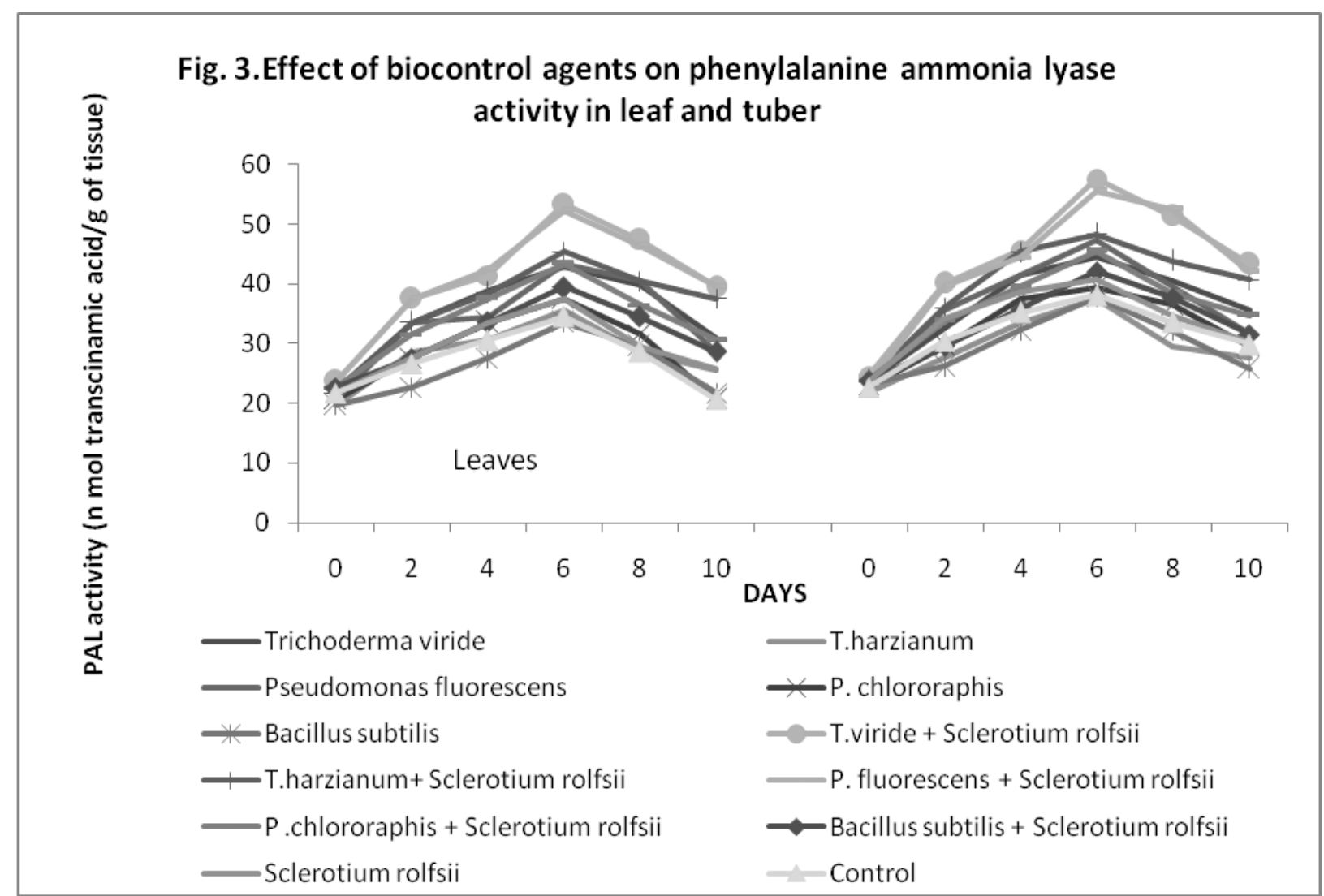

Fig.3 Effect of biocontrol agents on phenylalanine ammonia lyase activity in leaf and tuber

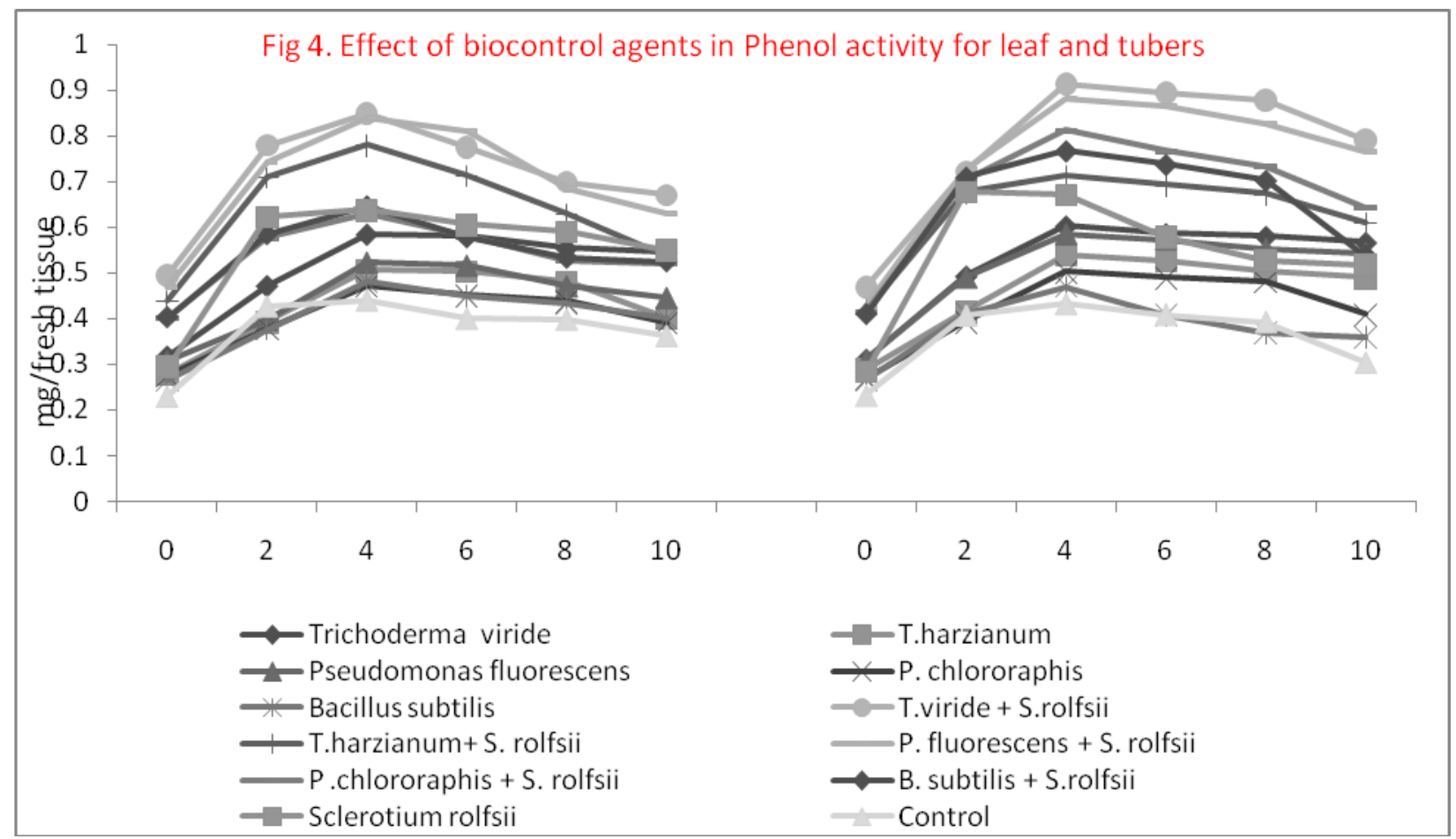

Fig.4 Effect of biocontrol agents in Phenol activity for leaf and tubers 
Phenylalanine ammonia lyase plays an important role in the biosynthesis of phenolic phytoalexins (Daayf et al., 1997). The increase in PAL activity indicates the activation of phenyl propanoid pathway. In the establishment phase of a pathogen within the host tissues, The product of PAL activity is transcinnamic acid which is an immediate precursor for the biosynthesis of salicylic acid, a signal molecule in systemic acquired resistance (SAR) (Klessig and Malamy, 1994).

Phenyl propanoid metabolism starts with the conversion of L-phenylalanine into transcinnamic acid by the enzyme phenylalanine ammonia-lyase (PAL) (Massala et al., 1980). In the present study, treatment with T.viride (TVB1), T. harzianum (THB1) P.fluorescens (SBHRPF2) P. chlororaphis (PA23) and B. subtilis (SBHRBS1) induced the plants to synthesize PAL when the plants were challenge inoculated with S.rolfsii. The activity reached the maximum level on four day after challenge inoculation in tropical sugarbeet leaf and tubers pretreated with the Soil application of $T$. viride, and $P$. fluorescens which was challenged with $S$. rolfsii. When groundnut plants were sprayed with $P$. fluorescens, increased activity of PAL was observed (Meena et al., 2000). Cucumber plants treated with $P$. corrugata had initially higher levels of PAL and levels were lower after challenging the plants with P.aphanidermatum (Chen et al., 2000). Prior treatment of anthurium seedlings with biocontrol agents triggered the plant defense mechanism in response to infection by $C$. gloeosporioides. Hence, it is speculated that among the various direct antagonistic tools, ISR is also the one indirect tool by which the tested biocontrol agents afforded resistance to anthurium against the pathogen (Thangeswari and Sankaralingam, 2013) addition to soil drench, foliar spray showed that PGPR and chemical defense inducers can be exploited to control take-all throughout the crop growing season. Often farmers seek products that prevent the disease from spreading after its appearance in the field. Most plant probiotic products are designed to be applied inthe soil. However, it is necessary to develop bacterial formulations to be applied under phyllosphere conditions (Ali Mahmood Jasem et al., 2018).concluded that soil application of Rhizospher and phyllosphere microorganism induced systemic resistance against soil borne pathogen in tropical sugarbeet ecosystem.

\section{References}

Ali Mahmood Jasem, Rouhallah Sharifi and Saeed Abbasi, 2018. Induced systemic resistance, to wheat take-all disease by probiotic bacteria. Journal of Plant Protection Research. Vol. 58, (3): 304310.

Bostock, R.M., R.J.S. KarbanThaler., P.D. Weyman and D.Gilchrist. 2001. Signal interactions in induced resistance to pathogens and insect herbivores. European J. Plant. Pathol., 107: 103111.

Cha JY, Han S, Hong HJ, Cho H, Kim D, Kwon Y, Kwon SK, Crüsemann M, Yong BL, Kim JF,2016. Microbial and biochemical basis of a Fusarium wiltsuppressive soil. ISME J 10(1):119129.

Chen. C., R.R. Belanger., N. Benhameu and T.C. Paullitz. 2000. Defense enzymes induced in cucumber roots by treatment with plant growth promoting rhizobacteria. Physiol. Mol. Plant Pathol., 56 : 13-23.

Chong Qin, Jiemeng Tao, Tianbo Liu, Yongjun Liu, Nengwen Xiao, Tianming Li, Yabing Gu,Huaqun Yinand Delong Meng.2019. Responses of phyllosphere microbiota and plant health to application of two different biocontrol agents. AMB Expr 9:42. 
Daayf, F., R. Bel-Rhlid and R.R. Belanger. 1997. Methyl ester of $p$-coumaric acid: A phytoalexin like compound from long English cucumber leaves. J. Chem. Ecol., 29: 1517-1526.

Dariush Ebadi Almas and Atefeh Rahmani Kamrod.2019. Defense responses of rice plant to Monographella albescens attack. Journal of Plant Protection Research. Vol. 59(4): 535-543.

Dickerson, D.P., S. F. Pascholati., A.E. Hagerman., L.G. Butler and R.L. Niholson. $1984 . \quad$ Phenylalanine ammonia lyase and hydroxyl cinnamate: CoA ligase in maize mesocotyls inoculated with Helminthosporium maydis or Helminthosporium carbonum. Physiol. Plant Pathol., 25:111-123.

Difco Manual. 1953. Difco laboratories Inc., Detroit, Michigan, USA

Elad. Y and I. Chet. 1983. Improved selective media for isolation of Trichoderma spp or Fusarium spp. Phytoparasitica, 11: 55-58

Fukui, R., M. N. Schroth, M. Hendson, J.G. Hancock and M.K. Firestone. 1994. Growth pattern and metabolic activity of Pseudomonas in sugarbeet spermospheres: Relationship to pericarb colonization by Pythium ultimum. Phytopathology, 84: 1331-1338

Hammerschmidt, R., E.M. Nuckles and J. Kuc. 1982. Association of enhanced peroxidase activity with induced systemic resistance of cucumber to Colletotrichum lagenarium. Physiol. Plant Pathol., 20:73-82.

Hammerschmidt, R. and J. Kuc. 1995. Induced resistance to diseases in plants. Klewer Academic Publishers, Dordsechtl., The Netherlands, 182 p.

Heil, M. 2001. The ecological concept of induced systemic resistance (ISR). Eur. J. Plant Pathol., 107: 137-146.

Jayaraman, K.S., M.N. Ramanuja., P.K.
Vijayaraghavan and C.S. Vaisyanathan. 1987. Oxidative enzyme in pearl millet. Food Chemistry, 24: 203.

Klessig, D.F and A.J. Malamy. 1994 . The salicylic acid signaling in plants. Plant Mol. Biol., 26:1439-1458.

King, B., M.K. Ward., and D.E. Raney. 1954. Two simple media for the demonstration of pyocyanin and fluorescin. J. Lab. Clin. Med., 44: 301-307.

Laemmli, H.K. 1970. Cleavage of structural proteins during the assembly of the head of bacteriophage $\mathrm{T}_{4}$. Nature, 227: 680685.

Leach, L.D. 1934. Quantitative determination of Sclerotium rolfsii in the soils of sugarbeet fields. Phytopathology, 24: 317-334.

M'Piga, P., R.R. Belanger, T.C. Paulitz, and N. Benhamou.1997. Increased resistance to Fusarium oxysporum f. sp. lycopersici in tomato plants treated with the endophytic bacterium Pseudomonas fluorescens strain 63-28. Physiol. Mol. Plant Pathol., 50: 301-320.

Massala, R., M. Legrand and B. Fritig. 1980. Effect of aminooxyacetate, a competitive inhibitor of phenylalanine ammonia-lyase, on the hypersensitive resistance of tobacco to tobacco mosaic virus. Physiol. Plant Pathol., 16: 213226

Mayer, A.M., E. Harel and R.B. Shaul. 1965. Assay of catechol oxidase a critical comparison of methods. Phytochemistry, 5: 783-789.

Meena, B., V. Ramomoorthy., T. Marimuthu and R. Velazhahan. 2000. Pseudomonas fluorescens systemic resistance against late leaf spot of groundnut. J. Mycol. Plant Pathol., 30: 151-158.

Mukhopadhyay, A.N. 1971. Sclerotium root rot of sugarbeet in India. Mycopath. Mycol. Appl. 44: 265-270. 
Nadlony, L and L. Sequira. 1980. Increase in peroxidase activities are not directly involved in induced resistance in tobacco. Physiol. Plant Pathol., 16: 1-8.

Nandakumar, R., S. Babu., R. Viswanathan., T. Raguchander and R. Samiyappan. 2001. Induction of systemic resistance in rice against sheath blight disease by plant growth promoting rhizobacteria. Soil Biol. Biochem., 33: 603-612.

Osburn, R.M., M.N. Schroth, J. G. Hancock and M. Hendson. 1989. Dynamics of sugarbeet seed colonization by Pythium ultimum and Pseudomonas species: effects on seed rot and damping - off. Phytopathology, 79: 709-716

Paramasivan,M., A. Chandrasekaran.,, S. Mohan and N.Muthukrishnan.2014. Ecological management of tropical sugar beet (TSB) root rot (Sclerotium rolfsii (Sacc.) by rhizosphere Trichoderma species. Archives of Phytopathology and Plant Protection. Vol. 47 (13) 1629-1644

Rangaswami, G. 1972. Diseases of Crop
Plants in India. Prentice Hall of India Pvt. Ltd, New Delhi, India. p.520.

Rangaswamy, G and Soumini Rajagopalan. 1973. Bacterial Plant Pathology. Tamil Nadu Agricultural University, Coimbatore, 129p.

Smith, J.A., D.W. Fulbright and R. Hammerschmidt. 1991. Rapid induction of systemic resistance in cucumber by Pseudomonas syringae pv syringae. Physiol. Mol. Plant Pathol., 35: 240246.

Thangeswari and Sankaralingam, 2013. Induction of defense-related enzymes in anthurium by application of fungal and bacterial biocontrol agents against Colletotrichum gloeosporioides. Int.J.Curr.Microbiol.App.Sci. 2(12): 661-670

You C, Zhang C, Feng C, Wang J, Kong F. 2015. Myroides odoratimimus, a biocontrol agent from the rhizosphere of tobacco with potential to control Alternaria alternata. Biocontrol 60(4):555-564.

\section{How to cite this article:}

Paramasivan Mookkan and Muthukrishnan. N. 2020. Induced Systemic Resistance by Rhizosphere and Phyllosphere Microorganism against Root Rot caused by Sclerotium rolfsii in Tropical Sugarbeet (TSB) Ecosystems. Int.J.Curr.Microbiol.App.Sci. 9(06): 2051-2066. doi: https://doi.org/10.20546/ijcmas.2020.906.252 